\title{
MANAJEMEN FASILITAS MULTIMEDIA MASJID AR-RAHMAH PERAK SURABAYA
}

\author{
Shobikhul Qisom \\ Sekolah Tinggi Ilmu Dakwah dan Komunikasi Islam (STIDKI) Ar-Rahmah, Jl. Teluk Buli I/5-7 Surabaya 60165, \\ Jawa Timur \\ e-mail: shobikhulqisom@stidkiarrahmah.ac.id
}

\begin{abstract}
The rapid development of technology is one thing that really needs to be considered. The role of multimedia is very influential for sensory comprehension and attracts the attention and interest of consumers or congregations. The Ar Rahmah Mosque in Surabaya has also utilized multimedia facilities in executing its programs. Good managerial ability with multimedia facilities is also a supporting factor for the Ar Rahmah Mosque that is not technologically illiterate. This study aims to determine how to manage multimedia facilities at the Ar Rahmah Mosque in Surabaya. Primary data collection is obtained through interview method with resource persons who play a direct role in the management of the Ar Rahmah Mosque, while secondary data is obtained through literature study. The data were analyzed descriptively qualitatively. Surabaya Ar Rahmah Mosque has equipped multimedia facilities to support its mosque program. The Ar Rahmah Mosque has also implemented management functions in multimedia facilities, from planning to monitoring functions. However, in its implementation there are still some technical and non-technical obstacles, so it is necessary to evaluate and improve the management system.
\end{abstract}

Keywords: Facilitiy management,Masjid Ar Rahmah, multimedia

\section{ABSTRAK}

Perkembangan teknologi yang begitu pesat merupakan salah satu hal yang sangat perlu diperhatikan. Peran multimedia sangat berpengaruh bagi daya tangkap indera dan menarik perhatian serta minat konsumen atau jama'ah. Masjid Ar Rahmah Surabaya juga telah memanfaatkan fasilitas multimedia dalam mesyi'arkan program-programnya. Kemampuan manajerial yang baik terhadap fasilitas multimedia tersebut juga menjadi faktor pendukung Masjid Ar Rahmah tidak gagap teknologi. Penelitian ini bertujuan untuk mengetahui cara manajemen fasilitas multimedia di Masjid Ar Rahmah Surabaya. Pengumpulan data primer diperoleh melalui metode wawancara dengan narasumber yang berperan langsung dalam manajemen Masjid Ar Rahmah, sedangkan data sekunder diperoleh melalui studi pustaka. Dat-data tersebut dianalisis secara deskriptif kualitatif. Masjid Ar Rahmah Surabaya telah melengkapi fasilitas multimedia untuk menunjang program kemasjidannya. Masjid Ar Rahmah juga telah menerapkan fungsi manajemen terdahap fasilitas multimedia, mulai dari fungsi perencanaan hingga pengawasan. Namun dalam pelaksanaannya masih ditemukan beberapa kendala teknis maupun non teknis, sehingga perlu dilakukan evaluasi dan perbaikan sistem manajemen.

Kata Kunci: Manajemen fasilitas, Masjid Ar Rahmah, multimedia 


\section{PENDAHULUAN}

Masjid memiliki kekuatan tersendiri dalam kalangan umat Islam, karena masjid merupakan satu-satunya lembaga yang dapat mendekatkan diri pada Allah Ta 'Ala. Masjid di beberapa negara Islam yang telah maju, memiliki pengaruh yang sangat besar dalam kehidupan sosial masyarakatnya Keberadaan masjid menduduki fungsi sentral dalam masyarakat karena umumnya masjid merupakan perwujudan asprirasi umat Islam. Selain, sebagai tempat melaksanakan ibadah, masjid dituntut sebagai agent of social changes (agen perubahan sosial) Masjid memiliki berbagai macam tujuan dan program yang secara ideal bertujuan untuk memelihara perilaku keagamaan dan perilaku lainnya yang ada dalam suatu kelompok masyarakat, dengan kata lain masjid mampu sebagai pranata sosial Islam (social instution). ${ }^{1}$

Menurut Muslim, aktualisasi dari peran masjid yang terjadi pada masa Nabi SAW, misalnya bisa dilakukan dengan: (1) pembangunan sarana fisik yang memadai, masjid hendaknya dibangun dengan persiapan yang sebaik-baiknya dalam berbagai aspek; (2) kegiatan ibadah mahdliah harus berjalan dengan teratur, sehingga bisa membantu untuk mendatangkan kekhusyu'an bagi mereka yang beribadah di sana; (3) sebagai pusat pendidikan, diarahkan untuk mendidik generasi muda Islam dalam pemantapan aqidah, pengamalan syariah dan akhlak; (4) sebagai pusat informasi Islam, dikelola secara modern dengan media internet termasuk dilengkapi dengan faks, email, website dan sebagainya; (5) Pusat dakwah diwujudkan dengan pembentukan lembaga da'wah, diskusi-diskusi rutin, kegiatan remaja masjid, penerbitan buku-buku, majalah, dan brosur dan media masa lainnya termasuk media elektronik. (6) Pusat penyelesaian masalah (problem solver) bisa diwujudkan dengan merekrut para pakar dalam berbagai disiplin ilmu, termasuk para ulama untuk memberikan solusi terhadap berbagai permasalahan yang timbul di tengah masyarakat. (7) Sebagai pusat kegiatan sosial, ekonomi dan politik, masjid didesain agar terasa dimiliki oleh semua golongan umat Islam dari kelompok, golongan dan partai apapun. Dengan demikian, setiap orang muslim merasa memiliki masjid tersebut dan merasa mendapat penjelasan yang sangat bermanfaat bagi masyarakat. ${ }^{2}$

Masjid mempunyai fungsi dan peranan yang sangat besar bagi kaum muslimin, dan mempunyai arti yang sangat luas dalam berbagai aspek kehidupan. Masjid merupakan barometer kegiatan kaum muslimin. ${ }^{3}$

Masjid memiliki fungsi strategis dalam masyarakat Islam. Selain sebagai tempat ibadah, masjid juga berfungsi sebagai media pembinaan umat secara holistic Rasulullah SAW membangun masjid pertama di kota Madinah dengan tujuan mencerahkan umat dan mengenalkan risalah ilahiah. Masjid bukan hanya digunakan untuk melaksanakan kegiatan

\footnotetext{
${ }^{1}$ Auliyah R. 2014. Studi Fenomenologi Peranan Manajemen Masjid At-Taqwa dalam Pemberdayaan Ekonomi Masyarakat Bangkalan. Jurnal Competence ( Journal Of Management Studies). 8 (1) :

${ }^{2}$ Mannuhunung S. Tenrigan A.M dan Didiharyono D. 2018. Manajemen Pengelolaan Masjid dan Remaja Masjid di Kota Palopo. Jurnal Pengabdian Masyarakat. 1 (1) : 14-21

${ }^{3}$ Said. N.M. 2016. Manajemen Masjid (Studi Pengelolaan Masjid Agung Al-Azhar Jakarta). Jurnal Dakwah Tabligh. 17 (1) : 94-105.
} 
ibadah ritual saja seperti shalat berjamaah, dzikir, membaca al-Quran, dan berdoa tetapi dapat juga digunakan untuk melaksanakan kegiatan-kegiatan sosial keagamaan dalam upaya mengembangkan masyarakat Islam. ${ }^{4}$

Masjid merupakan pranata keagamaan yang tak terpisahkan dari kehidupan spritual, sosial, dan kultural umat Islam. Keberadaan masjid dapat dipandang sebagai salah satu perwujudan dari eksistensi dan aspirasi umat Islam, khususnya sebagai sarana peribadatan yang menduduki fungsi sentral dalam kehidupan bermasyarakat. Mengingat fungsinya yang sangat strategis, maka penampilan dan pengelolaan masjid perlu dibina sebaik-baiknya agar dapat memberi manfaat bagi sumber daya di sekelilingnya, baik dari segi fisik bangunan maupun segi kegiatan pemakmurannya. Sehingga semestinya keberadaan masjid tidak hanya berfungsi sebagai pusat peribadatan semata, melainkan juga sebagai pusat pelayanan umat. ${ }^{5}$

Salah satu model kepemimpinan pendidikan perspektif Islam adalah kepemimpinan berbasis masjid, yang mana masjid adalah tempat bersatunya umat lslam dalam pelaksanaan peribadahan, baik ibadah secara vertikal kepada Allah (S.W.T) (hablum minallah) maupun ibadah yang terkait dengan sesama manusia atau yang disebut (hablum minannas). Karena itu, umat Islam wajib memakmurkan masjid, karena masjid merupakan tempat peribadatan, sarana pembinaan umat dan juga menjadi media efektif dalam mempersatukan umat Islam. Orang yang memakmurkan masjid itu adalah orang yang jelas terbukti keimanannya, dan ia hanya takut kepada Allah dan takut ancaman neraka-Nya.

Di Indonesia masjid dipahami sebagai tempat atau bangunan untuk menunaikan ibadah sholat umat Islam, baik bersifat perseorangan maupun jama'ah. ${ }^{6}$ Pada masa Rasulullah Shollallahu 'alaihi wa sallam, masjid tidak hanya berperan sebagai tempat ibadah, akan tetapi masjid menjadi pusat syi'ar Islam, seperti tempat latihan perang, pengobatan bagi para muslim yang terluka, menimba ilmu, dan lain sebagainya. Bahkan yang lebih strategis lagi, masjid dijadikan sebagai pusat pengembangan masyarakat agar dapat mendengarkan arahan-arahan dari Nabi Shollallahu 'alaihi wa sallam secara langsung tentang berbagai hal. ${ }^{7}$ Namun pada era modern saat ini, untuk menciptakan masjid dengan penerapan peran dan fungsi yang baik masih belum dapat dilakukan secara maksimal. Hal tersebut dikarenakan saat ini masjid tidak menjadi referensi utama umat dalam persoalan kehidupan sehari-hari sebagaimana yang diterapkan Nabi dan para sahabatnya. Oleh sebab itu, keinginan untuk mewujudkan masjid multifungsi yang pernah tercipta pada masa Rasulullah Shollallahu 'alahi wa sallam sekarang mulai memudar. ${ }^{8}$

Dalam rangka mewujudkan kembali peran dan fungsi masjid, aktifitas-aktifitasnya harus dikelola dengan manajemen yang baik dengan tidak melepaskan contoh fungsi masjid

\footnotetext{
${ }^{4}$ Ridwanullah A.I dan Herdiana D. 2018. Optimalisasi Pemberdayaan Masyarakat Berbasis Masjid. Jurnal Ilmu Dakwah :Academic Journal for Homiletic Studies. 12 (1) : 82-98

${ }^{5}$ Saputra A. dan Kusuma B.M.A. 2017. Revitalisasi Masjid Dalam Dialektika Pelayanan Umat Dan Kawasan Perekonomian Rakyat. Jurnal Al-IDARAH : Jurnal Manajemen dan Administrasi Islam. 1 (1) : 1-16.

${ }^{6}$ Aplikasia, Jurnal aplikasi Ilmu-ilmu Agama, Vol. V, No.2, Desember 2004: 1005-114

${ }^{7}$ Moh. E. Mukhsin Ayub. MK \& Ramlan Majoned., Manajemen Masjid Petunjuk Praktisbagi Per-pengurus. (gema insane press. 2001), Hal : 75-78

${ }^{8}$ Suprianto Abdullah,cahaya hikmah,peran dan fungsi masjid, ( Yogyakarta: Cahaya Hikmah, 2003),30
} 
pada masa Rasulullah shollallahu 'alaihi wa salam. Dengan manajemen yang baik, semua akan terorganisir, terkonsep, dan terstruktur dengan baik pula. GR. Terry dalam buku Principles of Management menyatakan bahwa: "Management is a distinct process consisting of Planning, Organising, Actuating and Controlling permormed to determined and accomplish stated objectives by the use of human being and other resourses." Manajemen merupakan suatu proses yang terdiri dari Perencanaan, Pengorganisasian, Penggerakan serta Pengawasan yang dilakukan untuk mencapai tujuan-tujuan yang telah ditentukan melalui sumber daya manusia dan sumber daya lainnya. ${ }^{9}$ Berdasarkan pengertian tersebut, maka tugas masjid selanjutnya adalah menyiapkan diri sebagai fasilitator umat dalam segala aspek persoalan kehidupan, sehingga dapat menjadi sarana pengembangan umat.

Setiap masjid pasti memiliki fasilitas sesuai dengan strata dan tingkatan dari masjid tersebut. Dan tentu Masjid Nasional atau Masjid Negara memiliki fasilitas yang lebih lengkap daripada masjid-masjid yang lain. Pada umumnya, fasilitas masjid dapat dibagi dua bagian, yaitu fasilitas utama dan fasilitas pendukung. Fasilitas utama dapat meliputi seperti Mimbar, Mihrab, Tempat adzan, Tempat wudhu, Kamar mandi, Toilet, Menara, dan lain sebagainya. Sedangkan fasilitas pendukung yaitu seperti kantor pengurus atau kesekretariatan, majlis ta'lim, perputakaan, baitul mal dan lain sebagainya. ${ }^{10}$

Perkembangan teknologi yang begitu pesat merupakan salah satu hal yang sangat perlu diperhatikan. Di masa mendatang, sektor teknologi akan menjadi sektor yang sangat dominan. Teknologi menjadi suatu hal yang berperan aktif dalam berbagai bidang (kompasiana.com, 2012). Oleh sebab itu, masjid harus ikut mengambil bagian di dalam memanfaatkan teknologi itu sendiri. Salah satu usaha memanfaatkan teknologi tersebut ialah dengan menyiapkan alat atau sarana pendukung multimedia agar mempermudah para jama'ah menjangkau informasi lebih banyak. Peran multimedia sangat berpengaruh bagi daya tangkap indera dan menarik perhatian serta minat konsumen atau jama'ah. Computer Technology Research (CTR) menyatakan bahwa persentase daya ingat seseorang hanya mampu $20 \%$ dari hal-hal yang dilihat dan $30 \%$ dari yang didengar. Namun persentase daya ingat seseorang akan meningkat menjadi 50\% apabila mendengar dan melihat secara langsung. Bahkan seseorang akan mampu mengingat sesuatu dengan persentase $80 \%$ dari apa yang didengar, dilihat, dan dikerjakan sekaligus.

Multimedia mampu menyajikan informasi yang dapat dilihat, didengar dan dilakukan sekaligus. ${ }^{11}$ Dari sisi penyampaian dan penerima informasi, keuntungan multimedia di antaranya adalah lebih komunikatif, fleksibel, interaktif, dan lebih leluasa menuangkan kreativitas. ${ }^{12}$ Perangkat lunak multimedia menyediakan tools dan programming language, sehingga pengguna bisa lebih kreatif dalam mengaplikasikannya. Agar syi'ar masjid lebih luas, berkesinambungan, dan terus berkembang, sangat bergantung pada cara merencanakan, mengadakan, dan mengelola alat atau fasilitas multimedia itu sendiri. Dengan melakukan

\footnotetext{
${ }^{9}$ Eman Seherman, SE.,M.Pd. Manajemen Masjid ; kiat sukses meningkatkan kualitas SDM melalui optimalisasi kegiatan umat berbasis pendidikan berkualitas unggul (Bandung: ALFABETA,2012), Hal: 25-26.

${ }^{10}$ Tim FOKKUS BABINROHIS Pusat, ICMI Orsat Cempaka Putih, Yayasan Kado Anak Yatim, Pedoman Manajemen Masjid, (Jakarta: Yayasan Kado Anak Muslim, 2004), 28-29.

${ }^{11}$ Munif, M.IT, Multimedia, Konsep \& Aplikasi Dalam Pendidikan, (Bandung,ALFABETA,2012), hal:6

${ }^{12}$ Ibid, hal.6-7
} 
pengelolaan yang baik terhadap fasilitas multimedia, maka keuntungan-keuntungan multimedia tersebut akan lebih mudah didapatkan.

Masjid Ar Rahmah merupakan salah satu masjid di Surabaya yang letaknya strategis, yaitu dekat dengan akses keluar-masuk tol Tanjung Perak, berada di dalam kompleks perumahan, dekat dengan perkantoran dan sekolah-sekolah. Selain itu, dengan adanya kampus STIDKI (Sekolah Tinggi Ilmu Dakwah dan Komunikasi Islam) serta berbagai lembaga dakwah dan pendidikan menjadikan masjid ini lebih istimewa. Masjid Ar Rahmah dikenal memiliki sistem kepengurusan terstruktur dan tersistematis, terutama terkait perencanaan, pengelolaan, dan perawatan fasilitas yang dimiliki. Masjid Ar Rahmah juga telah memanfaatkan fasilitas multimedia dalam mesyi'arkan program-programnya. Pemanfaatkan multimedia tersebut memberikan daya tarik tersendiri bagi Masjid Ar Rahmah dibandingkan masjid lainnya, sehingga masjid ini tidak sepi dari para jama'ah. Di samping itu, kemampuan manajerial yang baik terhadap fasilitas multimedia tersebut juga menjadi faktor pendukung Masjid Ar Rahmah tidak gagap teknologi. Penelitian ini bertujuan untuk mengetahui cara manajemen fasilitas multimedia di Masjid Ar Rahmah Surabaya.

Penelitian terdahulu yang hampir sama adalah penelitiannya, Ainul Huda, 2010, Fakultas Tarbiyah dan Keguruan Universitas Islam Negeri Sunan Kalijaga, dengan judul: Penggunaan Multimedia Berbasis Komputer Pada Pembelajaran Kosakata Bahasa Arab di MTS Nurul Ummah Kotagede Yogyakarta.

\section{METODE PENELITIAN}

Penelitian ini dilakukan di Masjid Ar Rahmah, Jalan Teluk Buli 1 No 3-5-7 Surabaya. Dalam penelitian ini yang digunakan penulis adalah pendekatan kualitatif, yaitu penelitian yang bersifat seni dan naturalistic karena penelitiannya dilakukan pada kondisi-kondisi alamiah atau natural setting. ${ }^{13}$ Menurut Lofland kata-kata dan tindakan adalah sumber data utama dalam penelitian kualitatif. Lebih dari itu adalah data tambahan seperti dekumen dan lainnya. ${ }^{14}$ Pengumpulan data primer diperoleh melalui metode wawancara dengan narasumber yang berperan langsung dalam manajemen Masjid Ar Rahmah, yaitu Ketua Takmir, staf pengelola multimedia, dan staf sarana prasarana. Sementara data sekunder diperoleh melalui studi pustaka baik berupa buku, jurnal, maupun situs di internet. Data yang telah diperoleh selanjutnya dianalisis secara deskriptif kualitatif yaitu dengan melakukan proses penggambaran terhadap keadaan sasaran sebenarnya dan apa adanya, sejauh apa yang penulis dapatkan dari hasil observasi, wawancara, dan juga dokumentasi. ${ }^{15}$ dengan lebih menekankan pada kondisi dan situasi yang diamati di lapangan.

\section{HASIL DAN PEMBAHASAN}

Dalam sub pembahasan ini peneliti akan memaparkan hasil proses pengumpulan data, yaitu hasil wawancara di lapangan yang kemudian akan disajikan dalam bentuk pemaparan

\footnotetext{
${ }^{13}$ Sugiono, Metode Penelitian Pendidikan, Pendekatan Kuantitatif Kualitatif dan R\&D,(Bandung: Alfabeta,2016), h.14

${ }^{14}$ Lexy J. Moleong,MA, Metodologi Penelitian Kualitatif, (Bandung, PT Remaja Rosdakarya,1989), 157.

15 Tjetjep Rohendi Rohidi, Analisis Data Kualitatif (Jakarta: UI Press, 1992), 15.
} 
secara detail atau tulisan deskripsi. Sebagaimana data yang diperoleh dari hasil penelitian, maka penyajian data di sini bertujuan untuk menjawab rumusan masalah yang diangkat. Adapun data hasil penelitian atau hasil wawancara lebih lanjut akan diuraikan sebagai berikut.

Dalam setiap kegiatan atau program di dalam sebuah organisasi, tentunya memiliki hal-hal yang melatar belakangi kegiatan tersebut diadakan. Sama halnya dengan kegiatan multimedia di Masjid Ar Rahmah memiliki beberapa faktor yang menjadi latar belakang di adakannya multimedia.

"Secara garis besar ada empat poin penting yang menjadi perhatian kami. Yang pertama ialah perlunya dakwah di Masjid Ar-Rahmah disebar lebih luas lagi. Kedua, perlunya sosialisasi program atau kegiatan kemasjidan yang mampu bekerja lebih masif dengan jangkauan yang jauh lebih luas. Ketiga, sebuah bentuk upaya untuk menyesuaikan diri dengan perubahan dan perkembangan zaman khususnya dalam area digital. Kemudian keempat yaitu agar mampu menarik perhatian lebih para generasi milenial saat ini agar lebih mendekatkan diri secara personal individunya maupun komunitasnya."16

Dari pernyataan di atas, dapat diketahui bahwa masjid tidak hanya menjadi tempat ibadah semata namun sebagai syi'ar atau dakwah islam disebarkan. Dan melihat perkembangan teknologi yang begitu pesat, masjid harus mampu mengambil peran di dalamnya. Seperti contoh dalam penyampaian kajian-kajian Islami, Jama'ah yang sekiranya tidak memiliki kesempatan untuk hadir langsung ke masjid, maka mereka dapat menyimak dan mengikuti kajian tersebut melalui sosial media yang ada, seperti Youtube, Instagram dan lain-lain. Sebagaimana yang disampaikan Pak Ibnu selaku staf kepengawasan multimedia di Masjid Ar Rahmah.

"Multimedia itu sebagai sarana pendukung kegiatan masjid untuk dokumentasi, promosi dan dakwah Masjid Ar Rahmah."17

Oleh sebab itu, fokus Masjid Ar Rahmah ini adalah mampu melayani masyarakat atau Jama'ahnya dengan pelayanan yang baik. Karena kenyamanan Jama'ah sangat berbanding lurus dengan pelayanan para pengurus di dalamnya. Sebagaimana yang disampaikan oleh Pak Sunari selaku Manager Sarpras Masjid Ar Rahmah.

"Itu harus bisa melayani dengan tiga unsur 'S', yang pertama adalah "Senyum" kemudian "Salam" kemudian "Sapa”. Eee.. di dalam pelayanan itu kita akan menyampaikan menanyakan apa, dan tujuannya, mau ketemu dengan siapa, kepentingannya, untuk menjaga apa? untuk menjaga hal-hal sesuatu yang tidak kita inginkan." 18

Sebagaimana yang disampaikan di atas, salah satu contoh pelayanan yang dilakukan adalah ketika salah satu Jama'ah mengalami kehilangan sandal, maka pihak ketakmiran akan menggantinya dengan barang yang baru. Oleh sebab itu, selain bergerak di bidang dakwah Islam, masjid juga memiliki fungsi-fungsi keagamaan lainnya serta fungsi sosial, di antaranya:

\footnotetext{
${ }^{16}$ Wawancara dengan Ustadz Al-Farabi Hasan Selaku Ketua Takmir Masjid Ar-Rahmah, pada tanggal 23 Februari 2019

${ }^{17}$ Wawancara dengan Pak Ibnu Chiwari Selaku Manager Pendidikan, pada tanggal 21 Februari 2019

${ }^{18}$ Wawancara dengan Pak Sunari Selaku Manager Sarpras, pada tanggal 22 februari 2019
} 
a. Tempat melakukan aktifitas pendidikan keagamaan

b. Tempat kaum muslimin bermusyawarah

c. Tempat konsultasi umat Islam

d. Tempat penyelenggaraan pernikahan

e. Tempat mengelola infaq, shodaqoh dan zakat ${ }^{19}$

Pengelolaan manajemen masjid harus terus ditingkatkan dan dikembangkan. Karena tujuan manajemen masjid ialah agar Jama'ahnya dapat terberdayakan dan merasakan kenyamanan di dalamnya.

Untuk menjawab rumusan masalah pada penelitian ini, perlu diketahui bahwa pada dasarnya dalam manajemen, fungsi-fungsi di dalam prosesnya tidak dapat dilepaskan.

1. Fungsi-fungsi di dalam proses manajemen

a. Perencanaan (Planning)

Dalam hal perencanaan terkait manajemen fasilitas multimedia pastinya memiliki perencanaan untuk jangka pendek, jangka menengah sampai pada jangka panjang. Di Masjid Ar Rahmah, perencanaan kegiatan khususnya terkait manajemen fasilitas multimedia, pimpinan dan beberapa pengurus takmir melakukan studi banding ke beberapa tempat.

"Jadi awal mula perencanaan multimedia yang hari ini sudah berjalan itu berangkat dari bahwa kita ingin masjid ini juga bisa mengikuti perkembangan zaman, memudahkan para jama'ah untuk bisa mengikuti ee.rangkaian-rangkaian dakwah yang ada di Masjid Ar Rahmah, maka perlu dibikinkan instrumennya. Muncullah sebuah ide agar kita membuat tim multi media yang nanti akan membawahi bank design namanya. Di situlah kami studi banding ke Al Irsyad pertama kali karena kami melihat bahwa di Surabaya ini (sepertinya) yang mempunyai standarisasi multimedia yang sudah lumayan bagus itu Al Irsayd dan Nurul Hayat. Lalu kami silaturrahim kesana dalam rangka untuk mengetahui bagaimana cara agar kita juga punya tim multimedia, ke Al Irsyad baru ke Nurul Hayat. Setelah ketemu dan sudah dapat ee.. beberapa usulan dari mereka, maka kita mulai membuat untuk tim multimedia dengan konsep dan peralatan yang tidak jauh berbeda dengan mereka, tapi kita masih kurang sebenarnya. Itu awal mulanya." 20

Dari pernyataan bahwa multimedia di Masjid Ar Rahmah tidak hadir secara tiba-tiba namun melewati bebrapa tahap seperti studi banding. Dan sejauh ini multimedia di Masjid Ar Rahmah sudah berjalan dan beroperasi hampir satu tahun.

"Mulai nempatin tempat ini itu pas semester 3 an, semester 3 berarti hampir satu tahun kemarin." 21

\footnotetext{
${ }^{19}$ Ahmadi Yani, Panduan Memakmurkan Masjid, (Jakarta: Al Qalam, 2009), hal. 12-17

${ }^{20}$ Wawancara dengan Ustadz Al Farabi Hasan Selaku Ketua Takmir Masjid Ar-Rahmah, pada tanggal 4 maret 2019

${ }^{21}$ Wawancara dengan Ikmal Nurman Selaku Manager Multimedia Masjid Ar-Rahmah, Pada Tanggal 22 Februari 2019
} 
Selanjutnya, dalam sebuah kegiatan organisasi terutama masjid, ada beberapa hal yang perlu diperhatikan terkait perencanaan kegiatan khususnya mempertimbangkan jangka waktu perencanaan, yaitu dari jangka pendek sampai pada jangka panjangnya. Oleh sebab itu, Masjid Ar Rahmah memiliki jangka waktu perencanaan bagi tim multimedia nya. Sebagaimana yang diuraikan oleh Ustadz Al Farabi selaku ketua takmir Masjid Ar Rahmah.

"Nah, rencanannya jangka pendeknya adalah kita pingin multimedia itu menjadi instrumen, sarana agar Jama'ah juga bisa mengikuti kajian-kajian, acara-acara yang ada di masjid melalui Youtube nya masjid. Sekarang kan masjid sudah punya, Ar Rahmah TV namanya. Nah itu, bisa mengikuti rangkaian itu dari ini ee.. dari rumah, via online begitu. "22

Sedangkan perencanaan terkait jangka panjang daripada tim multimedia Masjid Ar Rahmah Surabaya yaitu agar mampu menghasilkan profit tersendiri untuk masjid. Baik berupa pemasukan tambahan untuk masjid atau Jama'ah semakin bertambah aktif di dalam mengikuti serangkaian kegiatan dan kajiankajian di Masjid Ar Rahmah Surabaya.

"Jangka panjangnya adalah tim multimedia ini kelak bisa menjadi sarana untuk bisa membesarkan nama baik masjid di udara dan juga bisa menjadi bagian dari pemasukan masjid. Karena kalau misalnya followers nya sudah bisa mencapai angka 5.000, 10.000 bahkan 50.000 dan seterusnya dengan berjalannya waktu, kemungkinan besar itu bisa menjadi profit bagi masjid sendiri. "23

Setelah melalui tahap studi banding dan menyusun konsep serta perencanaan, maka pihak ketakmiran Masjid Ar Rahmah mulai melakukan proses pengadaan secara bertahap dengan melihat kondisi finansial masjid dan tingkat kebutuhan. Berikut peneliti mencantumkan perlengkapan atau fasilitas-fasilitas multimedia di Masjid Ar Rahmah, harga serta pemanfaatannya yang sudah beroperasi selama satu tahun:

\section{Lighting Yongnuo Digital YN300 III (1 pes):}

Diletakkan sebelah kiri bagian depan ruang utama Masjid Ar Rahmah, Digunakan untuk membantu pencahayaan saat peliputan kajian, imam dan lainlain., Dapat mengurangi noise yang berlebihan, Harga Rp.880.000,00

\section{Lighting HD-160 (1 pcs):}

Diletakkan di atas kamera utama, Membantu menjernihkan rekaman, Membantu menstabilkan warna dari pancaran cahaya pada Lighting utama, Harga Rp.465.000,00

\footnotetext{
${ }^{22}$ Wawancara dengan Ustadz Al Farabi Hasan Selaku Ketua Takmir Masjid Ar-Rahmah, pada tanggal 4 maret 2019

${ }^{23}$ Wawancara dengan Ustadz Al Farabi Hasan Selaku Ketua Takmir Masjid Ar-Rahmah, pada tanggal 4 maret 2019
} 


\section{Boya Sound Recorder (1 pes):}

- Digunakan untuk merekam audio saat kajian, imam dan lain sebagainya

- Audio menjadi lebih jernih dan minim noise

- Harga Rp.850.000,00

4. Handycam Sony NEX-VG30EH Full HD (1 pcs)

- Digunakan untuk merekam video dengan kualitas Full HD

- Digunakan setiap hari pada saat kajian

- Harga Rp.21.499.000,00

5. Tripod Velbon (1 pcs)

- Tripod kamera utama

- Digunakan setiap hari pada saat kajian

- Harga Rp.434.000,00

6. Tripod Takara ( 2 pcs)

- Tripon tambahan untuk kamera DSLR

- Harga Rp.157.000,00

7. Camera DSLR Canon EOS REBEL T4i (1 pes)

- Kamera tambahan yang digunakan hanya untuk mengambil gambar

- Harga Rp. 6.935.000,00

\section{Drone SYMA X5 SW (1 pcs)}

- Device baru dan masih dalam percobaan

- Belum digunakan untuk apapun pada kegiatan masjid

- Harga Rp.295.000,00

9. 1 Set PC Utama, Motherboard ASUS ROG B360-F Gaming (1 pcs), Processor Intel Core i7 $8^{\text {th }}$ Generation (1 pcs), Mouse Logitech $(1 \mathrm{pcs})$, Keyboard Logitech (1 pcs) dan Monitor LG (1 pcs):

- Digunakan untuk mengedit video kajian harian masjid

- Digunakan untuk membuat poster kajian atau kegiatan-kegiatan kemasjidan

- Mengelola akun sosial media masjid

- Dapat digunakan untuk pengoperasian softwere tingkat tinggi

- Digunakan hampir setiap hari

- Harga: Rp.2.650.000,00 (Motherboard ASUS), Rp.6.200.000,00 (Processor Intel Core i7), Rp.182.000,00 (Mouse Logitech), Rp.321.000,00 (Keyboard Logitech), Rp.

\section{1 Set PC Tambahan}

- Komputer pendukung yang digunakan ketika komputer utama full pengerjaan konten

- Pengoperasiannya hanya untuk softwere pertengahan

\section{Hard Disk WD Ekternal (1 pcs)}

- Digunakan untuk menyimpan hasil video yang sudah di upload ke setiap akun masjid 
- Proses pemindahan data dilakukan setiap satu pekan

12. TP-LINK portabel (1 pcs)

- Alat penangkap sinyal internet/modem

13. Flash Disk SanDisk 16 GB (1 pcs)

- Alat penyimpanan temporary untuk keperluan editing, transfer data dan lain-lain.

- Harga: Rp51.727,00

14. Memory Kamera SanDisk 32 GB 2 buah:

- Harga: Rp.200.000,00 × 2 = Rp.400.000,00

15. Memory Kamera SanDisk 16 GB 1 buah

- Harga: Rp.124.000,00

16. Memory Kamera SanDisk 8 GB 1 buah

- Harga: Rp.94.000,00

17. Baterai Charger ukuran tanggung:

- Xiomi 4 buah

- Panasonic 4 buah

- Energizer 4 buah

18. Adapter Charger Baterai:

- Taffwere 1 pcs

- Panasonic 1 pcs

19. Lemari Besi 1 buah

20. Meja 2 buah

21. Kursi 2 buah

22. Kabel Terminal 2 buah

23. Rompi Multimedia 3 buah

24. Kipas Angin Ruangan 1 buah

Secara kepemilikan, semua alat-alat atau perlengkapan multimedia di atas murni dari Masjid Ar Rahmah.

b. Pengorganisasian (Organizing)

Dirjen Bimas Islam dan Urusan Haji, Depag RI (2000; 3) menyatakan bahwa dalam menjalankan aktifitas manajemen, akan lebih efektif jika setiap kegiatan atau aktifitas tersusun dan terkelompokkan menjadi bagian-bagian tertentu agar semua kegiatan dapat berjalan sesuai dengan tujuan organisasi. Kemudian dari penyusunan bagian-bagian tersebut akan menghasilkan Struktur Organisasi dan sebuah perangkat, yaitu Job descrption. ${ }^{24}$

Secara umum, tim multimedia di Masjid Ar Rahmah sudah menjalankan fokus kerja atau Job descriptionnya dengan baik. Walaupun secara struktural masih belum memiliki penanggung jawab yang spesifik, akan tetapi kegiatan atau aktifitas dari tim multimedia Masjid Ar Rahmah dapat berjalan dengan baik.

\footnotetext{
${ }^{24}$ Eman Suherman, SE. M.Pd, Manajemen Masjid; Kiat Sukses Meningkatkan Kualitas SDM Melalui Optimaliasi Kegiatan Umat Berbasis Pendidikan Berkualitas Unggul, (Bandung, ALFABETA, 2012), hal. 86
} 
"Kalau dari struktural ee..karena kan sekarang ini belum ada penanggung jawab khusus orang gitu ya. Di sini belum ada penanggung jawab khusus gitu, jadi masih Ustadz Farabi gitu langsung ke kita. "25

Jadi, di dalam struktural kepengurusan tim multimedia secara khusus belum memiliki penanggung jawab, hanya saja para anggota multimedia telah membuat pembagian kerja atau job description serta SOP di dalamnya.

"Disini kami memiliki tiga anggota dan semua sudah mempunyai tugas masing-masing. "26

Berikut adalah job description dalam kepengurusan di Masjid Ar Rahmah Surabaya secara keseluruhan: ${ }^{27}$

Jabatan:

1. Pembina

2. Penanggung Jawab

3. Ketua

4. Sekretaris

5. Bendahara

6. Manager Program

7. Manager Hamas

8. Manager Sarpras

9. Manager Multimedia

10. Manager Pendidikan

11. Manager Kepemudaan

Team Keamanan (Security)

1. Martoha

2. Supandi

3. Farid

4. Tri
Nama:

: Ustadz Muhammad Sholeh Drehem, Lc

: Ustadz Ahmad Mudzoffar Jufri, Lc, MA

: Ustadz Ali Ridho, SS

: Ustadz Herma Musyanto, Ssi

: Ustadz Alfarabi, S.Hum

: Moh. Syafiudin, S.Pd,i

: Moh. Aziz Lakone

: Moh.Yunus, SE

: Yuda Prayitno

: Moh. Sunari

: Moh. Ikmal Nurman

: Ibnu Chiwari, ST

: Abdul Wadud

\section{Team Cleaning Service}

1. Fikri Najahin

2. Rizal

3. Maulana

4. Abduh Surabaya. ${ }^{28}$

Berikut adalah job description daripada tim multiemedia Masjid Ar Rahmah

Nama

Ringkasan Pekerjaan
: Muhammad Ikmal Nurman

: Meliput kajian pada jadwal yang telah ditentukan, mengedit serta mempublikasikannya melalui

\footnotetext{
${ }^{25}$ Wawancara dengan Ikmal nurman Selaku Staf Multimedia Masjid Ar-Rahmah, Pada Tanggal 22 Februari 2019

${ }^{26}$ Wawancara dengan Ikmal nurman Selaku Staf Multimedia Masjid Ar-Rahmah, Pada Tanggal 22 Februari 2019

${ }^{27}$ Wawancara dengan Ustadz Al Farabi Hasan selaku Ketua Takmir Masjid Ar-Rahmah, Pada Tanggal 23 Februari 2019

${ }^{28}$ Wawancara dengan Ikmal nurman Selaku Staf Multimedia Masjid Ar-Rahmah, Pada Tanggal 7 Maret 2019
} 
Youtube.

Unit Kerja

Nama

Ringkasan Pekerjaan

Unit Kerja

Nama

Ringkasan Pekerjaan

Unit Kerja
: Publikasi Masjid

: Abdurrahmah Dwisona

: Meliput kajian pada jadwal yang telah ditentukan, membuat konten dakwah berupa ceramah singkat dan video murottal Al-Qur'an di Instagram.

: Publikasi Masjid

: Jauhari Muiz

: Meliput kajian pada jadwal yang telah ditentukan, meringkas video ceramah dan mempublikasikannya ke Youtube.

: Publikasi Masjid

c. Penggerakan (Actuating)

Dalam penggerakan atau pelaksanaan kegiatan daripada tim multimedia di Masjid Ar Rahmah Surabaya, peneliti mengajukan pertanyaan terkait beberapa hal yang dapat mendukung untuk menjawab perumusan masalah dalam penelitian ini. Pertanyaan tersebut terkait apa saja bentuk tugas daripada tim multimedia Masjid Ar Rahmah serta bagaimana bentuk pembagian tugas dari masing-masing anggota.

"Ee.. jadi, kalau untuk di sini sih kita.. kita kan secara garis besarnya ngeliput semua kegiatan yang ada di sini. Tapi terutama ceramah-ceramahnya, dan ceramahnya juga dibatasin sih sama Ustadz Al farabi, ada beberapa ceramah yang nggak kita liput. Naa.. jadi kalau untuk masalah jobdec yaa masing-masing terserah kita, tapi Ana sendiri itu bagian yang ngedit video dari ceramah. Semua ceramah Ana yang edit videonya, yaa .. semuanya sampai masuk ke Youtube. Ngedit, terus nge-convert terus uploud, posting. Kalau Instagram ada lagi Sonna. Naa.. itu yang Instagram. Kalau yang Jo, dia yang ke video pendek. Jadi dia ee.. ngolah dari video yang udah di upload ke Youtube dan dia ngambil intisari yaa. yang lima menit gitu. Naa.. itu nanti Youtube, jadi Ana lagi yang mesti upload nya gitu. Jadi gambaran besarnya itu sih. "29

Jadi, sebagaimana yang disampaikan diatas bahwasanya secara garis besar tim multimedia memiliki tugas meliput kajian-kajian atau kegiatan-kegiatan masjid, akan tetapi ada beberapa kegiatan atau kajian yang tidak diliput atau direkam oleh tim multimedia. Dan hal tersebut sesuai dengan perintah ketua takmir selaku pengawas daripada tim multimedia Masjid Ar Rahmah. Selain meliput kegiatan dan kajian, tim multimedia juga memiliki tugas tambahan seperti membuat posterposter terkait kajian atau kegiatan-kegiatan masjid.

\footnotetext{
${ }^{29}$ Wawancara dengan Ikmal Nurman Selaku Manager Multimedia Masjid Ar-Rahmah, Pada Tanggal 22 Februari 2019
} 
"ee.. biasanya sih ada tugas tambahan kayak ee.. suruh buat poster, suruh buat video-video ee.. video perkenalan mau ada kegiatan ini, kayak gitu sih."30

Selain itu, peneliti mengajukan pertanyaan terkait bagaimana proses pengadaan fasilitas atau alat-alat daripada multimedia di Masjid Ar Rahmah Surabaya.

"Pengadaannya bertahap, sesuai dengan kebutuhan dan kemampuan finansial masjid. "31

Selain pernyataan di atas, pernyataan serupa juga disampaikan oleh Pak Sunari selaku Manager Sarpras Masjid Ar Rahmah.

"Jadi begini, untuk pengadaan sesuatu kebutuhan itu merupakan ee di usulkan atau permohonan dari setiap unit ke kesekretariatan,melalui kesekretariatan kemudian langsung diajukan kebijaksanaan kepada ee pimpinan dan pimpinan akan menunjuk kepada bendahara, dan bendahara berhak menanyakan apabila pernah dilakukan suatu pengadaan, 'Kenapa ee anu barang yang ada?', nah itu harus tahu alasannya entah ini sudah ndak modern, perkembangannya harus pakai software sekian itu harus bisa menjelaskan oleh pihak daripada unit itu sendiri yang bertanggung jawab. ${ }^{32}$

Jadi, pengadaan yang meliputi pembelian atau penambahan alat dilakukan secara bertahap dengan menyesuaikan anggaran kebutuhan masjid secara umum. Karena sebagaimana diketahui bahwasanya masjid bukanlah sebuah tempat, organisasi, lembaga atau institusi milik pribadi, akan tetapi masjid bergerak untuk umat. Oleh karena itu, baik pengeluaran maupun pemasuka harus jelas asalusulnya. Sebagaimana pernyataan dari Pak Sunari berikut.

“..karena kita beda pengelolaan di ee..lingkup milik umat ee dengan perkantoran pribadi atau perkantoran milik umum. Kalau perkantoran umum itu, setiap tahun itu ada upgrading naa kalau milik pribadi tergantung kebutuhan, kan gitu. Tetapi kalau milik umat ini, ee..hubungannya harus jelas antara kebutuhan dan kemampuan daripada ee..perangkat itu sendiri." 33

Kemudian peneliti memberikan pertanyaan untuk dapat menjawab rumusan masalah berikutnya, yaitu bagaimana proses perawatan daripada fasilitas multimedia di Masjid Ar Rahmah.

\footnotetext{
${ }^{30}$ Wawancara dengan Ikmal Nurman Selaku Manager Multimedia Masjid Ar-Rahmah, Pada Tanggal 22 Februari 2019

${ }^{31}$ Wawancara dengan Ustadz Al Farabi Hasan selaku Ketua Takmir Masjid Ar-Rahmah, Pada Tanggal 23 Februari 2019

${ }^{32}$ Wawancara dengan Pak Sunari selaku Manager Sarpras Masjid Ar-Rahmah, Pada Tanggal 22 februari 2019

${ }^{33}$ Wawancara dengan Pak Sunari selaku Manager Sarpras Masjid Ar-Rahmah, Pada Tanggal 22 februari 2019
} 
"Perawatan itu hanya diserahkan langsung kepada tim yang dipercaya. Namun, ada lemari untuk perawatan dan ruang khusus multimedia sebagai sarana pendukung perawatannya. "34

Akan tetapi, di dalam pelaksanaan nya, perawatan fasilitas multimedia selama ini belum memiliki bentuk alat atau instrumen khusus untuk mendukung perawatan fasilitas tersebut.

"Kalau perawatan sih (ehmm), nggak terlalu ya. Tapi sih, kalau misalkan untuk ee.. paling lebih meratiin ini nya sih ee.. kayak memori gitu, pokoknya yang kira-kira ngehambat buat ngerakam itu baru dilakukan. Karena sejauh ini sih belum terlihat ada kerusakan. Sejauh ini jadi masih aman. Walaupun sih memang harusnya tuh ada ya. Kayak kamera tuh butuh perawatan gitu. Soalnya kan kalau lama-lama nanti berjamur. "35

Dengan demikian, walaupun belum memiliki instrumen pendukung terkait perawatan fasilitas, alat-alat daripada multimedia di Masjid Ar Rahmah masih dapat bekerja dengan maksimal dan belum menemukan permasalahan atau kendala yang bersifat teknis di lapangan.

"Kita itu ketolongnya tu ee .. karena (mungkin ya) kamera ini kan sering kepakai, jadi ee.. otomatis karena sering kepakai tuh dia jadi ee.. jarang kena debu nya. Kan kalau sering kita taruh di lemari terus otomatis debu tuh lebih ngendap. "36

Sebagaimana yang disampaikan pada uraian di atas bahwa kendala-kendala teknis masih dapat terhindarkan karena intensitas pemakaian yang baik.

d. Pengawasan (Controling)

Dalam kegiatan pengawasan terkait manajemen fasilitas multimedia di Masjid Ar Rahmah Surabaya, tim pelaksana daripada multimedia Masjid Ar Rahmah belum memiliki staf pengawas khusus untuk mengontrol kegiatan, akan tetapi pihak ketakmiran khususnya pimpinan atau ketua takmir yang langsung memantau.

"Di sini belum ada penanggung jawab khusus gitu, jadi masih Ustadz Farabi gitu langsung ke kita. "37

Hal ini diungkapkan juga oleh ketua takmir Masjid Ar Rahmah, Ustadz Al Farabi Hasan.

\footnotetext{
${ }^{34}$ Wawancara dengan Pak Ibnu Selaku Manager Pendidikan Multimedia Masjid Ar-Rahmah, Pada Tanggal 21 februari 2019

${ }^{35}$ Wawancara dengan Ikmal Nurman Selaku Manager Multimedia Masjid Ar-Rahmah, Pada Tanggal 22 Februari 2019

${ }^{36}$ Wawancara dengan Ikmal Nurman Selaku Manager Multimedia Masjid Ar-Rahmah, Pada Tanggal 22 Februari 2019

${ }^{37}$ Wawancara dengan Ikmal Nurman Selaku Manager Multimedia Masjid Ar-Rahmah, Pada Tanggal 22 Februari 2019
} 
"Fungsi pihak ketakmiran masjid di sini adalah mengontrol dan mengawasi jika ada hal-hal yang tim pelaksana butuhkan atau ada kendala-kendala teknis ataupun non-teknis yang terjadi di lapangan." 38

Oleh karena itu, jika tim daripada multimedia Masjid Ar Rahmah menemukan kendala atau permasalah, baik teknis ataupun non teknis di lapangan, maka laporan terkait hal tersebut langsung diarahkan kepada pihak ketakmiran masjid Ar Rahmah, khususnya ketua. Selain itu, peneliti juga mengajukan pertanyaan terkait kendala yang kerap terjadi terkait pengelolaan multimedia baik secara fisik maupun non fisik. di sini peneliti melihat di antara kendala-kendala tersebut adalah kurangnya aktifitas komunikasi atau koordinasi antar unit.

"Jadi kalau selama ini memang ya kita ini masih kurang, komunikasi aktifnya masih kurang. Jadi kerjasamanya masih kurang antar unit. Jadi masih belum mencontohkan ee organisasi yang solid, karena apa, tiap unit mestinya harus ada koordinasi dan wajib ada ee koordinasi itu, karena keberhasilan organisasi itu karena kebersamaan bukan personal. Karena tidak adanya komunikasi, maka apa, perawatan tidak ada standarisasinya. "39

Selain kendala berupa kurangnya komunikasi antar unit, adapula kendalakendala seperti kurangnya tanggung jawab ketika terjadi peminjaman barang. Baik pengembalian yang melewati batas waktu peminjaman atau bahkan terjadi kerusakan ataupun kehilangan dengan barang tersebut.

"Yang pertama, peminjaman alat yang kadang kurang bertanggung jawab jika ada kerusakan atau kehilangan. Kemudian butuh anggaran yang besar untuk melengkapi sesuai spekulasi terkini." 40

Kemudian ungkapan terkait kendala juga disampaikan oleh staf pelaksana daripada multimedia, yaitu Ikmal Nurman.

"Kalau kendala dari alat sih ee.. sebenanya nggak terlalu besar, contoh kayak lighting, itu lighting itu buat Ana masih kurang, soalnya kenapa? ee.. kurangnya itu dari lighting besar, kan ada lighting yang cerah banget, ada yang redup kan. Kalau yang banget itu, kita kan masih posisikan yang di samping itu (samping mimbar), naa itu sebenarnya masih kurang itu. Harusnya itu dari atas atau dari yaa. Dari atas lah gitu, jadi si cahaya nya itu ke tengah, itu kan dari samping jadinya ke samping terus ee.. akhirnya gambar nya itu akhirnya yang cerah ada yang nggak, tapi untungnya ada yang kecil itu, dibantu sama yang kecil itu, jadi agak ngurangin sih ke bias. Yang itu kan kuning banget tapi di biasin sama yang putih itu. Ee.. terus kalau misalkan dari kendala kenerja sih lebih ke ini ya ee.. lebih ke waktu. Kadang kan misalkan kalau lagi ada kegiatan yang bareng, maksudnya kan kita di sini selain multimedia masjid kadang-kadang juga diminta

\footnotetext{
${ }^{38}$ Wawancara dengan Ustadz Al Farabi Hasan selaku Ketua Takmir Masjid Ar-Rahmah, Pada Tanggal 23 Februari 2019

${ }^{39}$ Wawancara dengan Pak Sunari selaku Manager Sarpras Masjid Ar-Rahmah, Pada Tanggal 22 februari 2019

${ }^{40}$ Wawancara dengan Pak Ibnu Selaku Manager Pendidikan Masjid Ar-Rahmah, Pada Tanggal 21 februari 2019
} 
bantuan dari yaa STIDKI, na dua-dua nya kan ini juga. Yaa itu aja misalkan ee.. di STIDKI ada kegiatan besar terus minta dibantuin dan itu sedangkan di masjid juga kan kegiatannya terus-terusan jalan, jadi itu kadang-kadang yaa.. kita harus ngalah, harus ada yang di stop dulu gitu tapi nanti dijalanin gitu tapi tetep jalan. Misalkan kayak kegiatan STIDKI, kita selesaikan yang di STIDKI dulu nanti yang video-video di stop dulu nanti dibuat lagi gitu, nanti udah selese baru di rapel gitu." 41

Dari pernyataan di atas, diketahui bahwa kendala dari para tim multimedia adalah selain bertugas sebagai tim multimedia untuk Masjid Ar Rahmah, mereka juga menjadi mahasiswa daripada kampus STIDKI Ar Rahmah. Di mana Masjid Ar Rahmah saat ini berada dalam satu kesatuan. Baik bangunan maupun kerjasamanya. Akan tetapi, dari pernyataan-pernyatan di atas, peneliti melihat bahwa sejauh ini tim multimedia bekerja dengan sangat baik, sehingga kendalakendala di atas dapat dihindari atau terminimalisir.

Berdasarkan penyajian data di atas, maka peneliti dapat menganisis terkait manajemen fasilitas multimedia di Masjid Ar Rahmah sebagai berikut:

1. Perencanaan (Planning)

Sebagaimana dalam penyajian data di atas, dapat diketahui bahwa pihak ketakmiran daripada Masjid Ar Rahmah Surabaya memiliki bentuk perencanaan waktu di dalam proses kegiatan manajemen fasilitas multimedia itu sendiri, baik perencanaan jangka pendek maupun jangka panjang tentunya setelah melalui tahap studi banding terlebih dahulu ke beberapa tempat seperti Masjid Al Irsyad Surabaya dan Nurul Hayat sesuai dengan pernyataan yang diungkapkan oleh ketua takmir Masjid Ar Rahmah selaku pengawas daripada tim multimedia di Masjid Ar Rahmah. Maka, dengan adanya rencana jangka pendek dan jangka panjang ini diharapkan dapat menjadi acuan dalam organisasi untuk dapat menjalankan atau melaksanakan tujuan organisasi terutama pada masa mendatang, walaupun perencanaan tersebut tidak tertuang dalam bentuk tulisan atau terencanakan secara sistemtis.

Adapun bentuk rencana jangka pendek daripada multimedia di Masjid Ar Rahmah, yaitu dapat menjadi instrumen atau sarana bagi para Jama'ah yang memiliki kendala untuk bisa hadir di masjid agar bisa mengikuti kajian-kajian, acara-acara atau kegiatan yang ada di Masjid Ar Rahmah. Salah satunya adalah melalui Youtube daripada Masjid Ar Rahmah. Sedangkan rencana jangka panjangnya adalah tim multimedia kelak dapat menjadi sarana promosi dalam rangka membesarkan nama Masjid Ar Rahmah. Selain itu, tim multimedia diharapkan menjadi bagian dari pemasukan masjid.

Dari beberapa bentuk perencanaan waktu di atas, barulah pihak ketakmiran mulai menyusun tim multimedia serta pengadaan fasilitas atau alat-alat dari pada multimedia sendiri.

\footnotetext{
${ }^{41}$ Wawancara dengan Ikmal Nurman Selaku Manager Multimedia Masjid Ar-Rahmah, Pada Tanggal 22 Februari 2019
} 
2. Pengorganisasian (Organizing)

Sebagaimana dalam penyajian data sebelumnya, pelaksanaan pengorganisasian manajemen fasilitas multimedia berjalan dengan baik dan sistematis, walaupun pada dasarnya belum mempunyai penanggung jawab secara khusus, akan tetapi para tim multimedia memilik job description masing-masing. Di antara job description dari tim multimedia secara umum ialah seperti meliput, merekam dan mendokumentasikan kegiatan-kegiatan, kajian-kajian atau acara-acara di Masjid Ar Rahmah, kemudian dimasukkan ke dalam proses editing untuk selanjutnya hasilnya akan diposting ke beberapa media sosial seperti Youtube dan Instagram.

3. Penggerakan (Actuating)

Dalam proses penggerakan ini, secara khusus peneliti akan membahas temuantemuan terkait proses pengadaan dan perawatan daripada fasilitas multimedia di Masjid Ar Rahmah Surabaya.

Diketahui bahwa proses pengadaan daripada fasilitas multimedia berlangsung secara bertahap dengan melalui beberapa pertimbangan seperti menyesuaikan kebutuhan kemampuan finansial dari masjid, sebagaimana yang telah disampaikan ketua takmir Masjid Ar Rahmah Surabaya dalam penyajian data di atas. Dalam prosesnya juga, pengadaan fasilitas ini melalui beberapa tahap, yaitu unit dari tim multimedia melakukan pelaporan kepada pihak kesekretariatan terkait alat yang akan diadakan. Kemudian pihak kesekretariatan akan meneruskan laporan kepada pimpinan, yaitu ketua takmir Masjid Ar Rahmah. Setelah pimpinan memberikan kebijakan berupa persetujuannya terkait pengadaan tersebut, maka pimpinan akan menunjuk pihak kebendaharaan untuk melanjutkan pengadaan, baik berupa penambahan atau penggantian alat atau sarana.

Secara garis besar dalam proses perawatannya, tim multimedia belum memiliki standarisasi serta alat khusus untuk merawat fasilitas yang ada di multimedia. Akan tetapi, multimedia memiliki beberapa sarana pendukung untuk merawat fasilitasnya, seperti ruangan yang khusus digunakan oleh para tim multmedia bekerja serta lemari khusus untuk menyimpan alat-alat multimedia seperti kamera, sehingga kendala-kendala kerusakan atau yang lain dapat terhindari. Selain itu, di kerenakan Masjid Ar Rahmah memiliki kegiatan yang banyak dan berjalan hampir setiap hari, maka otomatis multimedia akan bekerja sesuai dengan kegiatan yang ada. Oleh sebab itu, alat-alat atau instrumen dari multimedia ini akan bekerja aktif sehingga perawatannya menjadi lebih mudah karena pemakaian alat yang aktif dan berkelanjutan.

4. Pengawasan (Controlling)

Dari keterangan yang diperoleh peneliti di lapangan bahwasanya proses pengawasan berjalan dengan baik, walaupun secara struktur belum memiliki penanggung jawab khusus terkait pengawasan kerja para tim multimedia di Masjid Ar Rahmah Surabaya. Di karenakan tim multimedia masih terbilang baru, yaitu baru berjalan hampir satu tahun, maka kendala berupa teknis khususnya terkait alat masih dapat dihindari dan terminimalisir tentunya dengan kerjasama tim yang sangat baik sejauh ini. Akan tetapi, salah satu kendala dari para tim multimedia adalah selain 
bertugas sebagai tim multimedia untuk Masjid Ar Rahmah, mereka juga menjadi mahasiswa daripada kampus STIDKI Ar Rahmah. Di mana Masjid Ar Rahmah saat ini berada dalam satu kesatuan. Baik bangunan maupun kerjasamanya. Sehingga ketika pihak kampus mengadakan suatu kegiatan atau acara, maka tim multimedia inilah yang akan diminta untuk meliput atau mendokumentasikan acara tersebut, sehingga tim multimedia ini yang notabenenya adalah mahasiswa daripada kampus STIDKI Ar Rahmah ini akan menunda sejenak tugas mereka yang ada di Masjid Ar Rahmah dan menyelesaikannya kembali ketika tugas dari pihak kampus telah selesai.

\section{SIMPULAN}

Masjid Ar Rahmah Surabaya telah melengkapi fasilitas multimedia untuk menunjang program kemasjidannya. Adanya fasilitas multimedia tersebut diharapkan mampu mensyi'arkan dakwah secara lebih luas. Dan semoga pengelolaan fasilitas multimedia di Masjid Ar Rahmah ini bisa ditiru oleh takmir masjid yang lainnya untuk memaksimalkan peran masjid kepada jamaah dan umat. juga telah menerapkan fungsi manajemen terdahap fasilitas multimedia, mulai dari fungsi perencanaan hingga pengawasan. Namun dalam pelaksanaannya masih ditemukan beberapa kendala teknis maupun non teknis, sehingga perlu dilakukan evaluasi dan perbaikan sistem manajemen.

\section{DAFTAR PUSTAKA}

Aplikasia, Jurnal aplikasi Ilmu-ilmu Agama, Vol. V, No.2, Desember 2004: 1005-114 Auliyah R. 2014. Studi Fenomenologi Peranan Manajemen Masjid At-Taqwa dalam Pemberdayaan Ekonomi Masyarakat Bangkalan. Jurnal Competence ( Journal Of Management Studies). 8 (1)

Eman Seherman, SE.,M.Pd. Manajemen Masjid ; kiat sukses meningkatkan kualitas SDM melalui optimalisasi kegiatan umat berbasis pendidikan berkualitas unggul (Bandung: ALFABETA,2012)

Mannuhunung S. Tenrigan A.M dan Didiharyono D. 2018. Manajemen Pengelolaan Masjid dan Remaja Masjid di Kota Palopo. Jurnal Pengabdian Masyarakat. 1 (1) : 14-21

Moh. E. Mukhsin Ayub. MK \& Ramlan Majoned., Manajemen Masjid Petunjuk Praktisbagi Per-pengurus. (gema insane press. 2001), Hal : 75-78

Moleong, Lexy J. Metodologi Penelitian Kualitatif. Bandung, PT Remaja Rosdakarya,1989.

Munif, M.IT, Multimedia, Konsep \& Aplikasi Dalam Pendidikan, (Bandung:ALFABETA : 2012

Ridwanullah A.I dan Herdiana D. 2018. Optimalisasi Pemberdayaan Masyarakat Berbasis Masjid. Jurnal Ilmu Dakwah :Academic Journal for Homiletic Studies. 12 (1) : 82-98

Rohidi, Tjetjep Rohendi. Analisis Data Kualitatif. Jakarta: UI Press, 1992.

Said. N.M. 2016. Manajemen Masjid (Studi Pengelolaan Masjid Agung Al-Azhar Jakarta). Jurnal Dakwah Tabligh. 17 (1) : 94-105. 
Saputra A. dan Kusuma B.M.A. 2017. Revitalisasi Masjid Dalam Dialektika Pelayanan Umat Dan Kawasan Perekonomian Rakyat. Jurnal Al-IDARAH : Jurnal Manajemen dan Administrasi Islam. 1 (1) : 1-16.

Sugiono, Metode Penelitian Pendidikan, Pendekatan Kuantitatif Kualitatif dan R\&D. Bandung: Alfabeta, 2016.

Suprianto Abdullah,cahaya hikmah,peran dan fungsi masjid, Yogyakarta: Cahaya Hikmah 2003.

Tim FOKKUS BABINROHIS Pusat, ICMI Orsat Cempaka Putih. Pedoman Manajemen Masjid. Jakarta : Yayasan Kado Anak Muslim, 2004. 